\title{
Detecting ALK Gene Rearrangements in Lung Cancer Cytology Specimens
}

\section{Cooper WA ${ }^{1-3}$ and O'Toole SA ${ }^{1,2,4}$}

${ }^{1}$ Tissue Pathology and Diagnostic Oncology, Royal Prince Alfred Hospital, Camperdown, NSW, Australia

${ }^{2}$ Sydney Medical School, University of Sydney, NSW, Australia

${ }^{3}$ School of Medicine, University of Western Sydney, NSW, Australia

${ }^{4}$ The Kinghorn Cancer Centre, Garvan Institute of Medical Research, Darlinghurst, NSW, Australia

\begin{abstract}
Molecular testing for EGFR mutations and $A L K$ gene rearrangements has become a routine part of lung cancer pathological diagnosis, and is critical to determine the most effective therapies for patients with this poor prognosis cancer. $A L K$ gene rearrangements are seen particularly in adenocarcinoma of the lung and are associated with an excellent response rate to targeted inhibition with crizotinib in clinical trials for many patients whose tumours harbour this change. ALK gene rearrangement is generally observed at low incidence posing challenges for routine detection. Since a high proportion of lung cancers are inoperable at presentation, cytology plays a central role in diagnosis and provision of material for ALK testing. The advantages offered by cytology specimens for ALK and other molecular testing are becoming increasingly recognised - cytology specimens tend to have a lower proportion of contaminating stromal and other non-neoplastic cells and often have higher quality DNA than routine histology specimens. One challenge is the often limited amount of cytological material obtaining in many lung cancer cytology specimens. FISH testing for ALK gene rearrangement using a break-apart probe is the gold standard for testing although there is a strong role for immunohistochemistry in ALK testing. This review highlights key aspects of ALK testing in cytology specimens.
\end{abstract}

Keywords: Lung adenocarcinoma; $A L K$, Anaplastic lymphoma kinase; FISH; Immunohistochemistry

Abbreviations: ALK: Anaplastic Lymphoma Kinase; EML4: Echinoderm Microtubule Associated Protein-like 4; FISH: Fluorescent in situ Hybridization; IHC: Immunohistochemistry; NSCLC: NonSmall Cell Lung Carcinoma; NOS: Not Otherwise Specified; RT-PCR: Reverse-Transcriptase Polymerase Chain Reaction; TKI: Tyrosine Kinase Inhibitor

\section{Introduction}

Accurate subtyping of non-small cell lung carcinoma (NSCLC) is important due to implications for treatment selection and due to the unique mutational profile of different lung cancer subtypes [1]. Adenocarcinomas, tumours with an adenocarcinoma component or NSCLC- not otherwise specified (NOS) (in cytology or small biopsy samples) may harbour driver mutations amenable to targeted therapy [2]. It is estimated that about $70 \%$ of patients with NSCLC present with advanced stage disease not amenable to surgical resection, so only diagnostic cytology or small biopsy tumour samples are available for molecular analysis. There is evidence that cytology and small biopsy specimens have equivalent capacity to accurately subtype NSCLC [3]. Use of immunohistochemistry has become routine for distinction of NSCLC subtypes in cytology (and small biopsy) samples where morphology alone is insufficient [2] and in one study immunohistochemistry was less frequently required in cytology compared to small biopsy samples [3].

\section{$A L K$ Rearrangements in Lung Cancer}

Identification of driver mutations has become essential in lung cancer for selection of patients likely to respond to targeted therapies. A small proportion of lung adenocarcinomas harbour activating $A L K$ (anaplastic lymphoma kinase) gene rearrangements and these tumours are highly responsive to targeted tyrosine kinase inhibitors (TKIs) such as crizotinib [4].

The $A L K$ gene is located on the short arm of chromosome 2 and encodes a receptor tyrosine kinase that belongs to the insulin receptor family [5]. Activation of $A L K$ most commonly results from a small chromosomal inversion (with or without a small deletion) resulting in fusion of the intracellular kinase domain of $A L K$ with the amino terminal end of echinoderm microtubule associated protein-like 4 (EML4) [6-8]. Different variants of $E M L 4-A L K$ result from differing lengths of the $E M L 4$ gene being incorporated into the fusion gene $[6,9,10]$. More rarely, different partner genes fuse with $A L K$ including KIF5B (kinesin family member $5 \mathrm{~b}$ ), TFG (TRK-fused gene) and $K L C$-1 (kinesin light chain1) [11,12].The various $A L K$ fusion genes encode a constitutively activated tyrosine kinase $[7,11]$ that stimulates cell proliferation, survival and migration mediated through RAS/RAF/MAPK1, PI3K/ AKT and JAK3-STAT3 signalling pathways $[10,13]$. Mouse models expressing EML4-ALK develop multiple lung adenocarcinomas that are susceptible to pharmacologic ALK inhibition [14].

Studies from unselected Western populations mostly report $A L K$ rearrangements in about $4 \%$ of NSCLC [5]. We found $A L K$ rearrangements in $1 \%$ of lung adenocarcinomas in an Australian multicenter study [15]. The clinicopathological features associated with $A L K$ rearrangements are similar to the profile associated with $E G F R$ mutations. ALK rearrangements are associated with younger patient age and never-smokers or light smokers [6,15-19], however, racial and gender associations are less pronounced for $A L K$.

In NSCLC, $A L K$ rearrangements occur almost exclusively in

*Corresponding author: Wendy Cooper, Department of Tissue Pathology and Diagnostic Oncology, Royal Prince Alfred Hospital, Missenden Rd, Camperdown NSW 2050, Australia, Tel: (+612) 9515 7804; Fax: (+612) 9515 8405; E-mail: Wendy.Cooper@sswahs.nsw.gov.au

Received January 23, 2014; Accepted February 04, 2014; Published February 06, 2014

Citation: Cooper WA, O'Toole SA (2014) Detecting ALK Gene Rearrangements in Lung Cancer Cytology Specimens. J Cytol Histol 5: 216. doi:10.4172/21577099.1000216

Copyright: (c) 2014 Cooper WA, et al. This is an open-access article distributed under the terms of the Creative Commons Attribution License, which permits unrestricted use, distribution, and reproduction in any medium, provided the original author and source are credited. 
Citation: Cooper WA, O’Toole SA (2014) Detecting ALK Gene Rearrangements in Lung Cancer Cytology Specimens. J Cytol Histol 5: 216. doi:10.4172/2157-7099.1000216

adenocarcinomas [19] particularly with solid, acinar, cribriform with extracellular mucin or signet ring cell morphology in resection specimens [16,20-22]. In cytology (and small biopsy) specimens signet ring cells have been the only distinguishing morphological feature in $A L K$ rearranged lung adenocarcinomas [23].

While almost all $A L K$ rearrangements occur in adenocarcinoma, they may also occur in adenosquamous carcinomas [24] or combined small cell carcinoma and adenocarcinoma [25]. For this reason, it is recommended that cytology or small biopsy samples showing squamous or small cell carcinoma features can be considered for $A L K$ (and EGFR) testing if the clinical profile is suspicious (i.e., young never smoking patient) [26] as there is increasing recognition that the adenocarcinoma component of a mixed tumour may be unapparent in limited sample specimens.

As expected for a driver mutation, $A L K$ rearrangements almost always occur in tumours lacking other significant mutations such as EGFR or KRAS alterations $[15,19,20,27]$, however, rare cases of tumours harbouring activating alterations of both $A L K$ and $E G F R$ have been reported $[6,28,29]$.

\section{Identification of $A L K$ Rearrangements}

Recent consensus guidelines for molecular testing of lung cancer from the College of American Pathologists in conjunction with the International Association for the Study of Lung Cancer and the Association for Molecular Pathology [26] recommend testing all patients for EGFR mutations and $A L K$ rearrangements at the time of diagnosis of advanced stage lung adenocarcinoma. They recommend that EGFR testing is prioritised over other tests, followed by $A L K$ testing.

Fluorescence in situ hybridisation (FISH) using a dual colour probe that targets the breakpoint of the $A L K$ gene is the standard method for identifying $A L K$ rearrangements in current clinical practice and this technique has been validated in clinical trials [4]. FISH is a relatively costly and labour intensive assay that can be technically challenging to interpret in $A L K$ assays due to the small inversion resulting in a subtle split in signals. More recently studies have shown that ALK overexpression resulting from $A L K$ gene rearrangement can be identified using immunohistochemistry (IHC) using both the 5A4 clone $[28,30,31]$ and the newly available D5F3 clone $[15,32]$. IHC screening with confirmation by FISH provides a more cost-effective means of identifying $A L K$ rearrangements in low prevalence populations and can be used if carefully validated [26]. Furthermore, occasional tumours show ALK expression by IHC and are sensitive to ALK-TKI treatment despite being technically negative by FISH $[33,34]$.
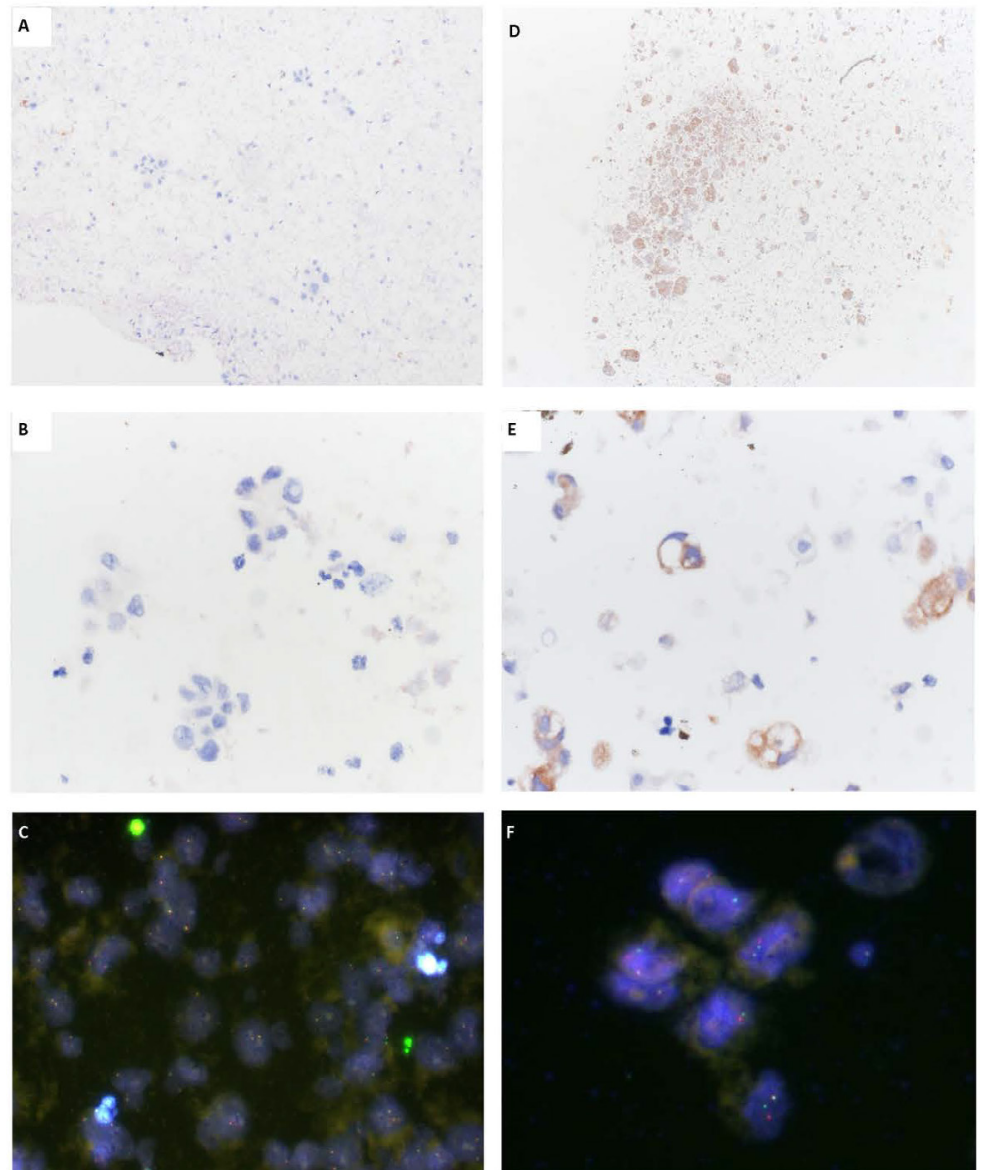

Figure 1: IHC and FISH for ALK in cytological specimens of lung adenocarcinoma. Cell block of pleural fluid with metastatic lung adenocarcinoma from an elderly woman. The tumour cells were negative for ALK IHC (A) low power and (B) high power. (C) FISH using a break apart probe was negative for ALK gene rearrangement with two fused red/green signals. Cell block from a fine needle biopsy of metastatic lung adenocarcinoma in a cervical lymph node from a 34 year old woman. The tumour cells were positive for ALK IHC (D) low power, (E) high power. (F) FISH showed ALK gene rearrangement with split red and green signals. 
The optimal tumour specimen for ALK FISH testing contains plentiful non-overlapping tumour cells that can easily be distinguished from interspersed inflammatory and stromal cells based on nuclear or architectural features using a high magnification fluorescent microscope [35]. It is imperative that a pathologist mark the appropriate area for FISH evaluation on an H\&E stained slide. Alcohol fixed specimens (or those that have undergone acid decalcification) should be avoided [35]. Pathological assessment for specimen suitability, cellularity and marking up of an appropriate area for expert FISH evaluation is essential to achieve accurate results [26]. Using a break-apart dual labelled FISH probe, cases are considered positive for $A L K$ gene rearrangement if they show split red and green signals in at least $15 \%$ of tumour nuclei with a minimum number of 50 cells analysed. Alternatively, an unbalanced $A L K$ rearrangement displays single red signals from the 3' probe with loss of the 5' green probe signal [35]. It is increasingly recognised that atypical patterns may also be observed on FISH and data on these unusual changes is currently being accumulated. Testing with second method such as immunohistochemistry may be helpful to resolve some of these atypical FISH patterns.

Reverse-transcriptase polymerase chain reaction (RT-PCR) can also be used to identify $A L K$ rearrangements so long as comprehensive primer sets are used to detect all possible known $A L K$-EML4 variants as well as other $A L K$ fusion partners [36]. This technique is not currently recommended by the CAP/IASLC/AMP guidelines for routine practice due to the difficulty obtained high quality RNA from formalin fixed paraffin embedded tissues [26]. However, RT-PCR is highly sensitive on fresh tumour samples and may be particularly suitable for cytology specimens [36].

\section{Cytology and $A L K$}

Testing for $A L K$ rearrangements may be undertaken on histology or cytology specimens from primary or metastatic sites. While FISH for $A L K$ rearrangements can be undertaken on a range of cytology specimens including conventional smears, cytospins or liquid-based preparations [35]we use paraffin-embedded cell block preparations from our cytology specimens in routine clinical practice. Smears have the advantage of avoiding nuclear truncation, tend to have high tumour cellularity and DNA quality and may be superior to formalin fixed cell block preparations [35], however, we find it more convenient to perform ALK IHC and FISH on consecutive sections cut from a cell block (Figure 1) where morphology can be compared to the H\&E stained slide and this is the current recommendation [26]. ALK gene rearrangements can be identified by FISH, RT-PCR and IHC using endobronchial ultrasound-guided transbronchial needle aspiration (EBUS-TBNA) specimens $[17,37,38]$ and some have reported almost $100 \%$ of lung cancer cytological specimens are suitable for $A L K$ FISH assessment [35]. ALK IHC can be performed with high sensitivity on smears from a range of lung adenocarcinoma specimens including pleural effusions, fine needle aspirates of lymph nodes and bronchial brushings [39], although in our practice we usually perform ALK IHC on cell block preparations.

\section{Summary}

The need to identify molecular markers that predict patient response to targeted therapies has revolutionised pathological assessment of lung cancer specimens. Testing for $A L K$ rearrangements should be considered in non-squamous NSCLC (i.e. adenocarcinoma and NSCLC-NOS in cytology samples) that lack EGFR mutations. A range of molecular techniques including IHC, FISH and sequencing based molecular genetic assays are expected to play an increasing role in the diagnostic workup of lung cancer and as many cases only have cytology specimens available, it is essential that cytologists are ready to meet the challenge.

\section{Acknowledgements}

WC has received funding from the National Foundation for Medical Research and Innovation.

SOT has received funding from the Cancer Institute NSW 10 CRF 1-07 and from the Sydney Breast Cancer Foundation.

An earlier version of this article was previously included in unpublished lecture notes at the Australian Society of Cytology Annual Scientific Meeting in Sydney 2013

\section{Conflict of interest statement}

WC and SO report having received honoraria for lectures and advisory boards from Pfizer, manufacturers of crizotinib.

\section{References}

1. Cooper WA, O'toole S, Boyer M, Horvath L, Mahar A (2011) What's new in nonsmall cell lung cancer for pathologists: the importance of accurate subtyping, EGFR mutations and ALK rearrangements. Pathology 43: 103-115.

2. Travis W, Brambilla E, Noguchi M, Nicholson AG, GeisingerK, et al. (2011) International Association for the Study of Lung Cancer/American Thoracic Society/European Respiratory Society International multidisciplinary classification of lung adenocarcinoma. J ThoracOncol 6: 244-285.

3. Sigel CS, Moreira AL, Travis WD, Zakowski MF, Thornton RH, et al. (2011) Subtyping of non-small cell lung carcinoma: a comparison of small biopsy and cytology specimens. J ThoracOncol 6: 1849-1856.

4. Kwak EL, Bang YJ, Camidge DR, Shaw AT, Solomon B, et al. (2010) Anaplastic lymphoma kinase inhibition in non-small-cell lung cancer. N Engl J Med 363 : 1693-1703.

5. Solomon B, Varella-Garcia M, Camidge DR (2009) ALK gene rearrangements: a new therapeutic target in a molecularly defined subset of non-small cell lung cancer. J ThoracOncol 4: 1450-1454.

6. Koivunen JP, Mermel C, Zejnullahu K, Murphy C, Lifshits E, et al. (2008) EML4ALK fusion gene and efficacy of an ALK kinase inhibitor in lung cancer. Clin Cancer Res 14: 4275-4283.

7. Soda M, Choi YL, Enomoto M, Takada S, Yamashita Y, et al. (2007) Identification of the transforming EML4-ALK fusion gene in non-small-cell lung cancer. Nature 448: 561-566.

8. Choi YL, Takeuchi K, Soda M, Inamura K, Togashi Y, et al. (2008) Identification of novel isoforms of the EML4-ALK transforming gene in non-small cell lung cancer. Cancer Res 68: 4971-4976.

9. Choi YL, Soda M, Yamashita Y, Ueno T, Takashima J, et al. (2010) EML4-ALK mutations in lung cancer that confer resistance to ALK inhibitors. N Engl J Med 363: $1734-1739$.

10. Shaw AT, Solomon B (2011) Targeting anaplastic lymphoma kinase in lung cancer. Clin Cancer Res 17: 2081-2086.

11. Rikova K, Guo A, Zeng Q, Possemato A, Yu J, et al. (2007) Global survey of phosphotyrosine signaling identifies oncogenic kinases in lung cancer. Cell 131: 1190-1203.

12. Takeuchi K, Choi YL, Togashi Y, Soda M, Hatano S, et al. (2009) KIF5B-ALK a novel fusion oncokinase identified by an immunohistochemistry-based diagnostic system for ALK-positive lung cancer. Clin Cancer Res 15: 31433149 .

13. Chiarle R, Voena C, Ambrogio C, Piva R, Inghirami G (2008) The anaplastic lymphoma kinase in the pathogenesis of cancer. Nat Rev Cancer 8: 11-23.

14. Soda M, Takada S, Takeuchi K, Choi YL, Enomoto M, et al. (2008) A mouse model for EML4-ALK-positive lung cancer. ProcNatlAcadSci U S A 105: 1989319897.

15. Selinger Cl, Rogers TM, Russell PA, O'Toole S, Yip P, et al. (2013) Testing for ALK rearrangement in lung adenocarcinoma: a multicenter comparison of immunohistochemistry and fluorescent in situ hybridization. Mod Pathol 26 : 1545-1553.

16. Rodig SJ, Mino-Kenudson M, Dacic S, Yeap BY, Shaw A, et al. (2009) Unique 
Citation: Cooper WA, O’Toole SA (2014) Detecting ALK Gene Rearrangements in Lung Cancer Cytology Specimens. J Cytol Histol 5: 216. doi:10.4172/2157-7099.1000216

clinicopathologic features characterize ALK-rearranged lung adenocarcinoma in the western population. Clin Cancer Res 15: 5216-5223.

17. Sakairi Y, Nakajima T, Yasufuku K, Ikebe D, Kageyama H, et al. (2010) EML4ALK Fusion Gene Assessment Using Metastatic Lymph Node Samples Obtained by Endobronchial Ultrasound-Guided Transbronchial Needle Aspiration. Clin Cancer Res 16: 4938-4945.

18. Shaw AT, Yeap BY, Mino-Kenudson M, Digumarthy SR, Costa DB, et al. (2009) Clinical features and outcome of patients with non-small-cell lung cancer who harbor EML4-ALK. J ClinOncol 27: 4247-4253.

19. Wong DW, Leung EL, So KK, Tam IY, Sihoe AD, et al. (2009) The EML4ALK fusion gene is involved in various histologic types of lung cancers from nonsmokers with wild-type EGFR and KRAS. Cancer 115: 1723-1733.

20. Inamura K, Takeuchi K, Togashi Y, Hatano S, Ninomiya H, et al. (2009) EML4ALK lung cancers are characterized by rare other mutations, a TTF-1 cell lineage, an acinar histology, and young onset. Mod Pathol 22: 508-515.

21. Jokoji R, Yamasaki T, Minami S, Komuta K, Sakamaki Y, et al. (2010) Combination of morphological feature analysis and immunohistochemistry is useful for screening of EML4-ALK-positive lung adenocarcinoma. J ClinPatho 63: 1066-1070.

22. Yoshida A, Tsuta K, Nakamura H, Kohno T, Takahashi F, et al. (2011) Comprehensive histologic analysis of ALK-rearranged lung carcinomas. Am J SurgPathol 35: 1226-1234.

23. Nishino M, Klepeis VE, Yeap BY, Bergethon K, Morales-Oyarvide V, et al. (2012) Histologic and cytomorphologic features of ALK-rearranged lung adenocarcinomas. Mod Pathol 25: 1462-1472.

24. Chaft JE, Rekhtman N, Ladanyi M, Riely GJ (2012) ALK-rearranged lung cancer: adenosquamous lung cancer masquerading as pure squamous carcinoma. J ThoracOncol 7: 768-769.

25. Toyokawa G, Taguchi K, Ohba T, Morodomi Y, Takenaka T, et al. (2012) First case of combined small-cell lung cancer with adenocarcinoma harboring EML4ALK fusion and an exon 19 EGFR mutation in each histological component. $J$ ThoracOncol 7: e39-41.

26. Lindeman N, Cagle P, Beasley M, Chitale D, Dacic S, et al. (2013) Molecular Testing Guideline for Selection of Lung Cancer Patients for EGFR and ALK Tyrosine Kinase Inhibitors: Guideline from the College of American Pathologists, International Association for the Study of Lung Cancer, and Association for Molecular Pathology. J ThoracOncol 8: 823-859.

27. Yip PY, Yu B, Cooper WA, Selinger Cl, Ng CC, et al. (2013) Patterns of DNA mutations and ALK rearrangement in resected node negative lung adenocarcinoma. J ThoracOncol 8: 408-414.
28. Sholl LM, Weremowicz S, Gray SW, Wong KK, Chirieac LR, et al. (2013) Combined use of ALK immunohistochemistry and FISH for optimal detection of ALK-rearranged lung adenocarcinomas. J ThoracOncol 8: 322-328.

29. Tiseo M, Gelsomino F, Boggiani D, Bortesi B, Bartolotti M, et al. (2011) EGFR and EML4-ALK gene mutations in NSCLC: a case report of erlotinib-resistant patient with both concomitant mutations. Lung Cancer 71: 241-243.

30. McLeer-Florin A, Moro-Sibilot D, Melis A, Salameire D, Lefebvre C, et al (2012) Dual IHC and FISH testing for ALK gene rearrangement in lung adenocarcinomas in a routine practice: a French study. $\mathrm{J}$ ThoracOncol 7: 348354.

31. Paik JH, Choe G, Kim H, Choe JY, Lee HJ, et al. (2011) Screening of anaplastic lymphoma kinase rearrangement by immunohistochemistry in non-small cell lung cancer: correlation with fluorescence in situ hybridization. $\mathrm{J}$ ThoracOncol 6: 466-472.

32. Conklin CM, Craddock KJ, Have C, Laskin J, Couture C, et al. (2013) Immunohistochemistry is a reliable screening tool for identification of ALK rearrangement in non-small-cell lung carcinoma and is antibody dependent. $\mathrm{J}$ ThoracOncol 8: 45-51.

33. Peled N, Palmer G, Hirsch FR, Wynes MW, llouze M, et al. (2012) NextGeneration Sequencing Identifies and Immunohistochemistry Confirms Novel Crizotinib-Sensitive ALK Rearrangement in a Patient with Metastatic Non-Small-Cell Lung Cancer. J ThoracOncol 7:e14-e16.

34. Sun JM, Choi YL, Won JK, Hirsch FR, Ahn JS, et al. (2012)A dramatic response to crizotinib in a non-small-cell lung cancer patient with IHC-positive and FISHnegative ALK. J ThoracOncol 7: e36-38.

35. Savic S, Bubendorf $L$ (2012) Role of fluorescence in situ hybridization in lung cancer cytology. ActaCytol 56: 611-621.

36. Tsao M, Hirsch F, Yatabe Y (2013) IASLC Atlas of ALK Testing in Lung Cancer Aurora: IASLC Press.

37. Nakajima T, Kimura H, Takeuchi K, Soda M, Mano H, et al (2010) Treatment of lung cancer with an ALK inhibitor after EML4-ALK fusion gene detection using endobronchial ultrasound-guided transbronchial needle aspiration. ThoracOncol 5: 2041-2043.

38. Kanaji N, Bandoh S, Ishii T, Tadokoro A, Watanabe N, et al. (2012) Detection of EML4-ALK fusion genes in a few cancer cells from transbronchial cytological specimens utilizing immediate cytology during bronchoscopy. Lung cancer 77 293-298.

39. Savic S, Bode B, Diebold J, Tosoni I, Barascud A et al (2013) Detection of ALK positive non-small-cell lung cancers on cytological specimens: high accuracy of immunocytochemistry with the 5A4 clone. J ThoracOncol 8: 1004-1011. 